\title{
Entrepreneurship Education: New Strategies in Unemployment during the Economic Crisis of Thailand
}

\author{
Suppamas Rattanapipat ${ }^{1}$, Benyada Laotanataworn², Laor Mamah ${ }^{3}$ \\ ${ }^{1,2,3}$ Faculty of Management Science, Yala Rajabhat University \\ ${ }^{1}$ suppamas.ratta@gmail.com, ${ }^{2}$ benyada.1@yru.ac.th, ${ }^{3}$ laor.jmamah@gmail.com
}

\begin{abstract}
The study aims to develop a structural equation model of entrepreneurship education during the current unemployment crisis of Thailand by using mixed methods approach. In part of quantitative research, the research tool was questionnaires. Data were collected from 420 samples. Structural Equation Modeling (SEM) was conducted for analyzing the model with empirical data. In part of qualitative research, the key informants was 5 person. Data gathering conducted by in-depth interview which were semi-structured interview. The major findings showed that factors that affect the entrepreneurship education were institutional setting, contents of course, teaching methods and individual factor. Considering the structural equation model of entrepreneurship education during the current unemployment crisis of Thailand had a good fit with the empirical data $\left(\chi^{\wedge} 2=556.45, \mathrm{df}=213\right.$, RMSEA $=0.054, \mathrm{CFI}=0.95$, SRMR=0.068). Teaching methods had the highest direct effect on entrepreneurship education, while institutional setting had the highest indirect effect. This new framework can be used to inform thinking in the area of entrepreneurship education to address the unemployment crisis.
\end{abstract}

Index Terms

Entrepreneurship Education, Unemployment, Economic Crisis

Article Received: 10 August 2020, Revised: 25 October 2020, Accepted: 18 November 2020

\section{Introduction}

In order to meet the occurred from the impact of Covid-19 on the economy through both direct (generated by domestic lockdown) and indirect (supply and demand shocks in supply chains, including tourism) channels is likely to be severe. The impact on workers within the impacted sectors will come in the form of reduced working hours and wages or even complete jobless. The public sector will need to adjust its solutions towards more consistent support of the most vulnerable and in consideration of mid to long-term COVID-19 recovery objectives [1]. Entrepreneurship has long been offered as the panacea for poor economic growth and high rate of unemployment. In many countries, the rate of population growth oversteps employment growth, necessitating the need to promote entrepreneurship as a means of creating employment and alleviating poverty [2] [3] [4].

Policymakers emphasized the importance of start-ups and encouraged college and university students to engage in entrepreneurship endeavors by promoting entrepreneurship education to address unemployment. A major assumption in these developments is that entrepreneurship education increases students' career prospects and employability, either through enabling them to become self-employed persons or through increasing their potential value as more enterprising employees. Consequently, lots of efforts are being put into advancement of entrepreneurship education in formal university curriculum [5] [6].

Although there is considerable consensus on the importance of entrepreneurship education until recently there has been no systematic investigation of the relationship of entrepreneurship education and unemployment [7]. It must be studied by empirical testing to implement theoretical entrepreneurship education concepts in practice.
According to the unemployment rate of Thai people which remained high and the working hour of employed people which constantly decreased will affect the income and other factors of households. New graduated, young and high levels of education workforces are still unemployed. In Q3/2020, there were 7.4 hundred thousand unemployed persons. This was equal to 1.90 percent of unemployment rate that was similar to the previous quarter at 1.95 percent, which was during a severe COVID-19 pandemic. Young and high level of education workforces were the majority of unemployed persons. Considering the unemployment rate by the level of education, it was found that the undergraduate degree had been the highest among other levels. Whereas the unemployment rate of workforces aged between 15-19 years old and 20-24 years old had risen to 9.4 percent and 7.9 percent respectively during this quarter as well. It indicated that young and high level of education workforce was the group that needed a continual care [8]. As mentioned before, Thailand is currently experiencing rapid growth in terms of its unemployment and consequently the complexity in terms of the administration to address the need to the young and high level of education workforce requires immediate attention.

Consistent with these points, to achieve promote a more flexible labor market may help mitigate the consequences and help to increase workers, promotion of entrepreneurship skills development for both new graduates to be ready to work and those who have already worked or have a job to have more skills or to have new skills that will enable future entrepreneur is necessary [8] [9].

Many universities have introduced entrepreneurship education to promote the interest of under graduates to becoming future entrepreneurs [10] [11] [12]. Despite the exposure to entrepreneurship education in Thailand Universities, many graduates still find it difficult to be gainfully employed for a long time after graduation. 
Entrepreneurship education to which students are exposed to on campus seems not to be a workable solution to unemployment [13] [14]. Most recent college and university graduates fall in this category and it is becoming increasingly necessary to get more and more of them to engage in self-employment. There is need therefore to find out the factors affecting entrepreneurship universities in Thailand. This is largely because there is lack of significant research in the area for sustainable economic growth to which employment is a part. A standard and culturally-based model for entrepreneurship education during the current unemployment crisis of Thailand needs to be established.

By conducted research in southern part of Thailand, as the south is a multicultural region, racial and religious. The entrepreneurship education implementing by providing opportunities for all sectors to participate in problem solving based on the concept of entrepreneurship education, which lead to achieve of implementation for unemployment that would be matched up with the way of life in the characteristics of that area. This would result in high quality engage in self-employment in southern part of Thailand.

\section{Research Objectives}

The objectives of this research article were 1)identify factors influencing entrepreneurship education during the current unemployment crisis in Southern of Thailand, and 2) to develop a structural equation model of entrepreneurship education during the current unemployment crisis in Southern of Thailand.

\section{Research Methods}

\section{A. Research Design}

This study used a mix-method approach as its research methodology in type of convergent parallel design [15]. Convergent parallel design mixed methods is to provide a comprehensive analysis of the research problem by converges or merges quantitative and qualitative data the research problem by converges or merges quantitative and qualitative data. The researchers collect and analyze two independent strands of quantitative and qualitative data in a single phase. The quantitative strand, the research tool was five-point Likert scales questionnaires. Data were collected from 420 undergraduate students in higher education institutions in the southern of Thailand who will graduate and entering the labor market in 2021. Structural Equation Modeling (SEM) was conducted for analyzing the model with empirical data. Data analysis was conducted by using descriptive statistics to analyze the basic statistics of variables to create a correlation matrix. Then, construct validity, construct reliability, and average variance extracted were performed by confirmatory factor analysis. Path analysis to determine the good fit with the empirical data of structural equation model. The qualitative strand, the key informants was 5 people from a group of graduates entering the labor market, university, labor government officials, entrepreneur, and academics who are involved in labor operations. Data gathering conducted by in-depth interview which were semi-structured interview.

\section{B. Research Process}

Research process of this research has developed into 3 steps consisted of preparation, procedure, and conclusion results. Steps were shown in Fig. 1.

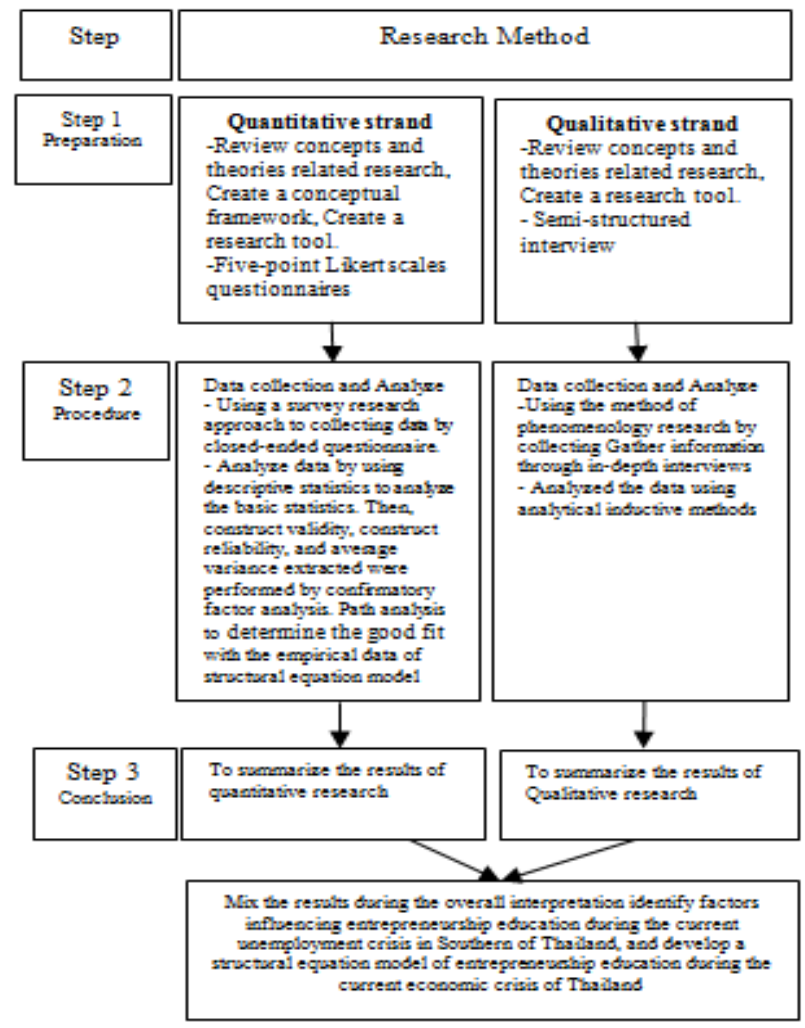

Fig.1 Research process for the develop a structural equation model of entrepreneurship education during the current unemployment crisis in Southern of Thailand

\section{Results}

\section{Structural model}

The overall fit of the structural model was good, with $\chi 2=556.45, \quad \mathrm{df}=213, \quad \mathrm{RMSEA}=0.054, \quad \mathrm{CFI}=0.95$, $\mathrm{SRMR}=0.068$ ). As a result of this, in the current study, it could be said that model shows fit to all data. Standardized path coefficients (direct, indirect and total effects) are calculated for all the variables that were in the model. The results of the analysis are demonstrated in Table 1. Path coefficients of alternative model are shown in Fig.1

Table.1 Standardized path coefficients (direct, indirect and total effects) in the Structural Model

\begin{tabular}{|c|c|c|c|c|c|}
\hline \multirow[t]{2}{*}{$\begin{array}{l}\text { Dependence } \\
\text { variable }\end{array}$} & \multirow[t]{2}{*}{ Pathway } & \multicolumn{4}{|c|}{ Independence variable } \\
\hline & & $\begin{array}{l}\text { Institutional } \\
\text { setting }\end{array}$ & $\begin{array}{l}\text { Contents } \\
\text { of course }\end{array}$ & $\begin{array}{l}\text { Teaching } \\
\text { methods }\end{array}$ & $\begin{array}{l}\text { Individual } \\
\text { factor }\end{array}$ \\
\hline \multirow{3}{*}{$\begin{array}{l}\text { Contents of } \\
\text { course }\end{array}$} & $\mathrm{DE}$ & $0.13^{* *}$ & - & - & - \\
\hline & IE & - & - & - & - \\
\hline & TE & $0.13^{* *}$ & - & - & - \\
\hline \multirow{3}{*}{$\begin{array}{l}\text { Teaching } \\
\text { methods }\end{array}$} & $\mathrm{DE}$ & $0.20^{*}$ & $0.18^{* *}$ & - & - \\
\hline & IE & $0.12^{*}$ & - & - & - \\
\hline & TE & $0.32^{*}$ & $0.18^{* *}$ & - & - \\
\hline \multirow{3}{*}{$\begin{array}{l}\text { Entrepreneurs } \\
\text { hip education }\end{array}$} & DE & $0.55^{* *}$ & $0.43^{* *}$ & $0.61^{* *}$ & $0.30^{*}$ \\
\hline & IE & $0.31^{* *}$ & $0.11^{* *}$ & - & - \\
\hline & $\mathrm{TE}$ & $0.81^{* *}$ & $0.53^{* *}$ & $0.61^{* *}$ & $0.30^{*}$ \\
\hline
\end{tabular}


The model confirms that 4 factors: Institutional setting, contents of course, teaching methods, and individual factor possessed effects on entrepreneurship education. Teaching methods had the highest positive direct effects on entrepreneurship education, followed by institutional setting, contents of course, and individual factor with the standardized path coefficients of 0.610 .550 .43 and 0.30 respectively. While institutional setting had indirect effect on entrepreneurship education with effect sizes 0.31 , which teaching methods as a mediator. Besides, the contents of course also had positive indirect effect on entrepreneurship education with effect sizes 0.11 . The hypothesis testing of direct effect between latent variables in the model, it was found that 6 hypotheses were accepted.

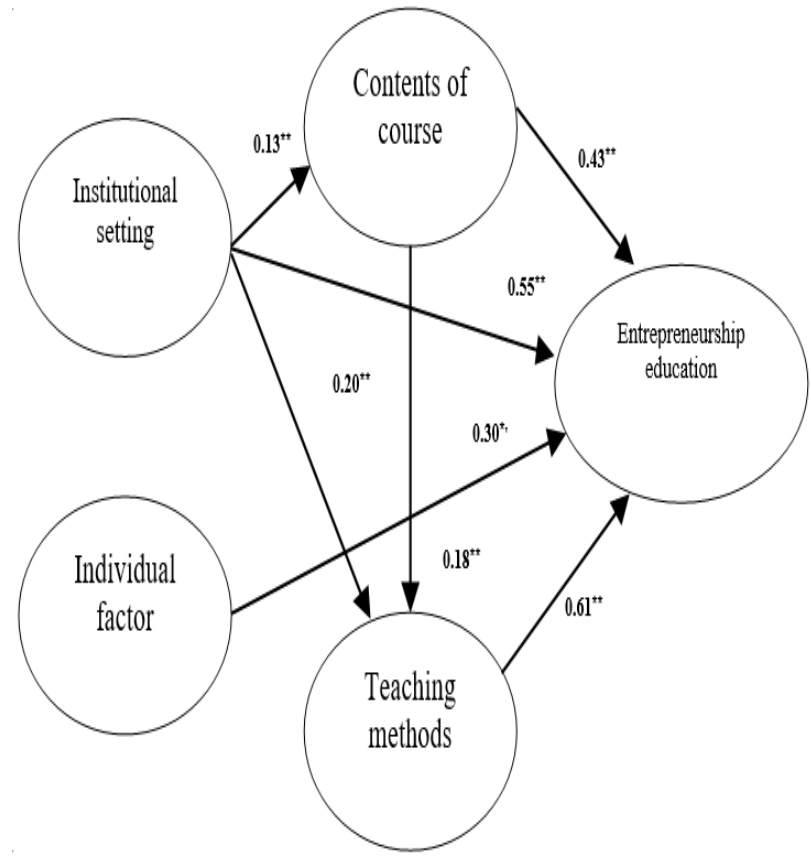

Fig.2 structural equation model of entrepreneurship education during the current unemployment crisis in Southern of Thailand

\section{Quantitative and qualitative data analysis results}

The results of the quantitative and qualitative data analyzes in the blended approach research showed that there were 4 factors influencing the entrepreneurship education during the current unemployment crisis of adolescents: institutional setting, contents of course, teaching methods, and individual factor. The results of the analysis are demonstrated in Table 2
Table.2 A comparison of the data analysis of quantitative and qualitative factors that influence entrepreneurship education during the current unemployment crisis in Southern of Thailand

\begin{tabular}{|c|c|c|}
\hline \multirow{2}{*}{\begin{tabular}{|l|} 
factors \\
influencing \\
entrepreneurship \\
education
\end{tabular}} & \multicolumn{2}{|c|}{ The results of the analysis } \\
\hline & Quantitative & Qualitative \\
\hline \begin{tabular}{|l|} 
Institutional \\
setting
\end{tabular} & $\begin{array}{l}\text { had the positive } \\
\text { direct effects with } \\
\text { the standardized } \\
\text { path coefficients of } \\
0.55 \text { at the } \\
\text { significance level } \\
\text { of } 0.01 \text { and had } \\
\text { indirect effect on } \\
\text { entrepreneurship } \\
\text { education with } \\
\text { effect r sizes } \\
0.31 \text {,which } \\
\text { teaching methods } \\
\text { as a mediator. }\end{array}$ & $\begin{array}{l}\text { Labor and education } \\
\text { professionals focus } \\
\text { on entrepreneurial } \\
\text { education; it is } \\
\text { believed that the } \\
\text { entrepreneurship } \\
\text { education to be able } \\
\text { to solve the problem } \\
\text { of unemployment the } \\
\text { context of the } \\
\text { educational } \\
\text { institution is very } \\
\text { important. "Before } \\
\text { making } \\
\text { entrepreneurship the } \\
\text { education success } \\
\text { must be start with the } \\
\text { support of r the } \\
\text { institution such as } \\
\text { organizational culture } \\
\text { and structure come } \\
\text { first". }\end{array}$ \\
\hline \begin{tabular}{|l|} 
Contents \\
course
\end{tabular} & $\begin{array}{l}\text { had the positive } \\
\text { direct effects with } \\
\text { the standardized } \\
\text { path coefficients of } \\
0.43 \text { at the } \\
\text { significance level } \\
\text { of } 0.01 \text { and had } \\
\text { indirect effect on } \\
\text { entrepreneurship } \\
\text { education with } \\
\text { effect sizes } 0.11 \text {, } \\
\text { which teaching } \\
\text { methods as a } \\
\text { mediator. }\end{array}$ & $\begin{array}{l}\text { Students get to know } \\
\text { what makes them } \\
\text { become } \\
\text { entrepreneurs } \\
\text { depends on the } \\
\text { knowledge } \\
\text { entrepreneurial } \\
\text { program with } \\
\text { complete learning } \\
\text { content. "Before } \\
\text { thinking about doing } \\
\text { any business we also } \\
\text { need to know first } \\
\text { what knowledge we } \\
\text { need to learn and } \\
\text { have to disciplinary". }\end{array}$ \\
\hline $\begin{array}{l}\text { Teaching } \\
\text { methods }\end{array}$ & $\begin{array}{l}\text { had the positive } \\
\text { direct effects with } \\
\text { the standardized } \\
\text { path coefficients of } \\
0.61 \quad \text { at the } \\
\text { significance level } \\
\text { of } 0.01\end{array}$ & 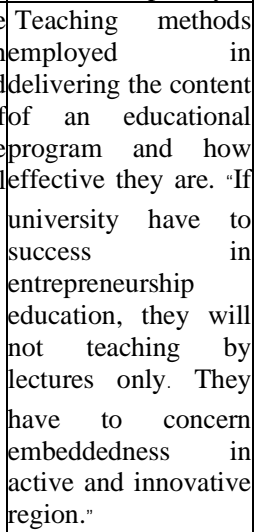 \\
\hline Individual factor & $\begin{array}{l}\text { had the positive } \\
\text { direct effects with } \\
\text { the standardized } \\
\text { path coefficients of } \\
\text { o.30 at the } \\
\text { significance level } \\
\text { of } 0.05 \\
\end{array}$ & $\begin{array}{l}\text { What will make } \\
\text { them able to become } \\
\text { to self-employment } \\
\text { intention or not } \\
\text { depends on self- } \\
\text { efficacy and attitude } \\
\text { towards } \\
\text { entrepreneurship. } \\
\text { "The completion of } \\
\text { entrepreneurial } \\
\text { education it is not } \\
\text { from the institution } \\
\text { only, bu from the }\end{array}$ \\
\hline
\end{tabular}




\begin{tabular}{|c|c|c|}
\hline \multirow{3}{*}{$\begin{array}{l}\text { factors } \\
\text { influencing } \\
\text { entrepreneurship } \\
\text { education }\end{array}$} & \multicolumn{2}{|c|}{ The results of the analysis } \\
\hline & Quantitative & Qualitative \\
\hline & & $\begin{array}{l}\text { individual factor of } \\
\text { how they think about } \\
\text { entrepreneurship and } \\
\text { he has to believe in } \\
\text { his own abilities as } \\
\text { well." }\end{array}$ \\
\hline
\end{tabular}

\section{Discussions}

\section{Teaching methods}

Teaching methods had the highest positive direct effects on entrepreneurship education during the current unemployment crisis of Thailand due to academic entrepreneurship does not involve a single event, but rather a continuous process composed of a series of events. A deeper understanding of academic entrepreneurship can, therefore, be achieved through a multi-step process that identifies the actors, activities and key success factors associated with each stage of the process. That is why university must work on each of the stages of the entrepreneurship education process [16].

\section{Institutional setting}

Institutional setting had the highest positive total effects on entrepreneurship education. General institutional (university) strategies have to joy relation to entrepreneurial activities in the regional environment and its importance for entrepreneurship education, thus positioning the university as a key contextual element in itself. Universities are affected by the regional governance and institutional economy. Additionally, university policy including institutional governance and leadership, organizational culture, strategy and purpose, and institutions' approaches to the commercialization of research and technology relating to the university and programme context are all influential context elements framing entrepreneurship education [16].

\section{Contents of course}

Contents of course had the positive direct effects on entrepreneurship education due to students get to know what makes them become entrepreneurs depends on the knowledge of entrepreneurial program with complete learning content. Entrepreneurship skills aim to tackle the barrier of lack of entrepreneurial knowledge, skills and attitudes and entrepreneurship experience. They equip student with skills and competences such as opportunity recognition, business planning, including soft skills such as sense of initiative, creativity, autonomy and teamwork. These skills and competences will be beneficial for their own (future) business or for working as an employee, while also helping young people become more aware of selfemployment as a career option [17].

\section{Individual factor}

This factor had the positive direct effects on entrepreneurship education. Additionally, individuals with high independency self-efficacy and attitude towards entrepreneurship, groundbreaking behaviors and risk appetite are able to suggest and implement new ideas to achieve the entrepreneurship education goals. The completion of entrepreneurial education it is not from the institution only, but from the individual factor of how they think about entrepreneurship and he has to believe in his own abilities as well [18].

\section{Recommendations}

\section{A. Recommendations for Practices}

1. Institutional setting had the highest positive total effects on entrepreneurship education. Universities need to focus on entrepreneurship educational design, in order to stimulate self-employment such as facilities required to effectively facilitate entrepreneurial learning in the university such as classrooms, vocational skill centers, business incubator what the center does to support for student entrepreneurial initiatives. The institutional setting also encompasses management support -funding for entrepreneurship research - whether funds are provided to further entrepreneurship within the university.

2. Teaching methods is very important factor influencing entrepreneurship education. Today, any education system should prepare students to work in a rapidly changing, dynamic, entrepreneurial and global environment by fostering the skills, attributes and behaviors that students need to improve both creative and critical thinking. This new scenario requires a paradigm shift for the academic world that should incorporate new teaching methodologies. Entrepreneurship education professionals should be able to create an open environment in which students develop the confidence to take risks and learn from their successes and failures. Active learning, Project-based learning, problembased learning, real-life situation, case studies, gamification, service learning, participation in real projects and work placements in companies or organizations are all active methodologies that can foster the development of entrepreneurship

3. Contents of course is important factor influencing entrepreneurship education. Students should learn about business planning and accessing start-up financing through the setting up of simulation or real business enterprises. It is important for students to gain the basic skills for starting and operating a business. However, there has an increasing trend to adopt multidisciplinary module that teaches about enterprise, entrepreneurship and innovation. Current entrepreneurship education in vocational training emphasizes on business development and ensuring that students get real-world knowledge.

4. Individual factor is important factor influencing entrepreneurship education. Universities need to focus on aspiring entrepreneur may be unable to maximize the learnings from his/her entrepreneurship training because of the hearing impairment which can affect his/her maximum participation in the learning environment. Such personal 
limitation affects the student's ability to convert the lecture to functioning of being entrepreneurially knowledgeable. Furthermore, the opportunity which a student has to undertake entrepreneurship education can also be seen as an individual factor because the knowledge and skills acquired can influence how he/she is able to convert other resources into the functioning of being an entrepreneur. This crucial role of entrepreneurship education in inculcating in the students, the skills, knowledge and attitudes required for being an entrepreneur.

\section{B. Recommendations for Further Research}

1. The process of implementing the concept of entrepreneurship education may not be able to operate successfully in a short time. Therefore, it should conduct further research be set to longitudinal study.

2. This structural equation model should be tested with empirical data in the context of entrepreneurship education in other areas by selecting the appropriate latent and observable variables in the context.

\section{Conclusion}

In conclusion, the findings from the analysis of both quantitative and qualitative showed that the increasing importance of entrepreneurship education and also looks at about the devolution of unemployment crisis. The model confirms that 4 factors: institutional setting, contents of course, teaching methods, and individual factor possessed effects on entrepreneurship education. Teaching methods had the highest positive direct effects on entrepreneurship education, followed by institutional setting, contents of course, and individual factor respectively. While institutional setting and contents of course had indirect effect on entrepreneurship education, which teaching methods as a mediator. Therefore when governments have to address to solving the unemployment, the problems become more importance so administrators should be concern about these constructs to provide entrepreneurship education so that a functional capacity can be maintained for unemployment, national economic development and transition.

This structural equation model in entrepreneurship education is successfully tested with empirically data. Over time, an empirically validated theory of entrepreneurship education may emerge by systematically development. Adding to the knowledge of entrepreneurship education theory focuses on the implementation as a means of creating employment and alleviating poverty

\section{References}

[1] United Nations in Thailand, "COVID-19 employment and labour market impact in Thailand". Retrieved on 6th December 2020, from https://www.un.or.th/wpcontent/uploads/2020/06/Impact-

Assessment-of-COVID-19-on- employment-and-labour-market-inThailand-.pdf.

[2] Ikebuaku, K., \& Dinbabo, M, "Beyond entrepreneurship education: business incubation and entrepreneurial capabilities", Journal of Entrepreneurship in Emerging Economies, 2018.

[3] González Sánchez, V.,M, "Selfemployment, knowledge and economic growth: An empirical study for latin american countries", Contemporary Economics, 12, 473-484, 2018.

[4] Hernández-Sánchez, B. R., Cardella, G. M., \& Sánchez-García, J. C. , "Psychological factors that lessen the impact of COVID-19 on the selfemployment intention of business administration and economics' students", latin america. International Journal of Environmental Research and Public Health, 17(15), 5293, 2020.

[5] Lin, S. and $\mathrm{Xu}, \mathrm{Z}$, "The factors that influence the development of entrepreneurship education: Based on the case of China", Management Decision, Vol. 55 No. 7, pp. 1351-1370, 2017.

[6] Thomassen, M.L., Williams Middleton, K., Ramsgaard, M.B., Neergaard, H. and Warren, L, "Conceptualizing context in entrepreneurship education: a literature review", International Journal of Entrepreneurial Behavior \& Research, Vol. 26 No. 5, pp. 863-886, 2019.

[7] Dvouletý, O, "What is the relationship between entrepreneurship and unemployment in visegrad countries?" Central European Business Review, 6(2), 42-53, 2017.

[8] Office of the National Economic and Social Development Council, "Thailand's Social Outlook of Q3/2020" Retrieved on 10th December 2020, from https://www.nesdc.go.th/ewt_dl_link.php? nid $=5493$.

[9] Pardo-Garcia, C., \& Barac, M, "Promoting employability in higher education: A case study on boosting entrepreneurship skills", Sustainability, 12(10), 4004, 2020. 
[10] Njeje, D. O. R. E. E. N, "Factors affecting entrepreneurship education and it's effect on entrepreneurial intentions among university students", 2015.

[11] Shi, L., Yao, X., \& Wu, W, "Perceived university support, entrepreneurial selfefficacy, heterogeneous entrepreneurial intentions in entrepreneurship education", Journal of Entrepreneurship in Emerging Economies, 2019.

[12] Hoang, G., Le, T.T.T., Tran, A.K.T. and $\mathrm{Du}, \mathrm{T}$, "Entrepreneurship education and entrepreneurial intentions of university students in Vietnam: the mediating roles of self-efficacy and learning orientation", Education + Training, Vol. 63 No. 1, pp. 115-133, 2020.

[13] Cheevapruk, S., \& Siriwong, P, "Development of standard criteria for entrepreneurial university" (Doctoral dissertation, Silpakorn University), 2020

[14] Chariya Korsukthaweekhoon, "The studying of entrepreneurial motiavation and intention of higher education students in Thailand" (Doctoral dissertation, Bangkok University), 2019.

[15] Creswell, J. W., \& Clark, V. L. P, "Designing and conducting mixed methods research", Thousand Oaks, CA: Sage Publications, 2011.

[16] Errasti, N., Bezanilla, M. J., García-Olalla, A., Auzmendi, E., \& Paños, J, "Factors and maturity level of entrepreneurial universities in Spain", International Journal of Innovation Science, 2018.

[17] Oyelola, O. T., Igwe, N. C., Ajiboshin, I. O., \& Peluola, S. B, "Entrepreneurship education: Solution to youth unemployment", Nigeria. Journal of Poverty, Investment and Development, 5(2014), 149-157, 2014.

[18] Ziyae, B., \& Tajpour, M, "Designing a comprehensive model of entrepreneurial university in the science and technology parks", World Journal of Entrepreneurship, Management and Sustainable Development, 2016 